\title{
Zmienność parametrów fizykochemicznych torfów w strefie przypowierzchniowej torfowiska w dolinie Strugi Wodnej (Wysoczyzna Lubartowska)
}

\author{
Pawel Rydelek ${ }^{1}$
}

\begin{abstract}
Variability of physicochemical parameters of peats in the subsurface zone of the fen in the Struga Wodna valley (Lubartów Plateau). Prz. Geol., 69: 867-872: doi: 10.7306/2021.48

A b s $\operatorname{tr}$ a $\mathrm{c}$. The paper presents the results of research on variability of basic physical and chemical parameters of peats from a small fen in the Struga Wodna valley on the Lubartów Plateau. The variability of organic matter content, moisture content, $p H$ and cation exchange capacity (CEC) was analysed. Apart from descriptive statistics, geostatistical methods were also used, including the analysis of semivariograms. All determined parameters showed high variability, including spatial variability. The analysis of the semivariograms showed that for each of the parameters there is a nugget effect, indicating high local variability. The statistically highest variability, expressed by the coefficient of variation, was shown by peat moisture content, while the moisture content showed the highest spatial autocorrelation. The use of geostatistical methods allowed identifying zones with different properties within the fen, and describing the spatial autocorrelation of individual parameters.
\end{abstract}

Keywords: peat, fen, variability of physicochemical parameters, geostatistics, semiwariogram

Procesy zachodzące w torfowiskach w trakcie akumulacji oraz w etapach późniejszych charakteryzują się różnym nasileniem w zależności od budowy torfowiska i prowadzą do przestrzennego zróżnicowania właściwości fizykochemicznych torfów w obrębie poszczególnych torfowisk. Zmienność wartości liczbowych parametrów fizykochemicznych w torfach jest związana przede wszystkim z warunkami panującymi w trakcie sedentacji, wyrażonymi przez rodzaj powstającego torfu (Hobbs, 1986). Największy wpływ na rodzaj powstających torfów ma budowa geologiczna i związany z tym sposób zasilania torfowisk oraz rodzaj występujących roślin torfotwórczych (Ingram, 1983; Okruszko, 1994; Tobolski, 2000). Zmienność właściwości w obrębie torfów tego samego rodzaju jest związana $\mathrm{z}$ procesami zachodzacymi $\mathrm{w}$ torfowiskach $\mathrm{w}$ trakcie i po fazie akumulacji, z których największy wpływ mają procesy rozkładu substancji organicznej oraz dostawa materiału mineralnego spoza torfowisk (Rydelek, 2013). Spośród procesów wpływających na zawartość i skład substancji organicznej należy wymienić m.in.: naturalne procesy rozkładu substancji organicznej związane z wahaniami zwierciadła wód podziemnych i warunkami utleniająco-redukcyjnymi panującymi $\mathrm{w}$ torfowisku oraz procesy wywołane eksploatacją torfu i melioracją torfowisk, przyczyniającymi się do zmian w stosunkach wodnych w ich obrębie. Efektem obniżenia zwierciadła wód podziemnych $\mathrm{w}$ torfowisku jest postępujący proces murszenia, powodujący zmiany właściwości fizykochemicznych torfów występujących w warstwach przypowierzchniowych (Hobbs, 1986; Myślińska, 2016).

Zróżnicowanie parametrów torfów jest problemem często opisywanym w literaturze, jednak zdecydowanie częściej dotyczy zmienności w profilach pionowych (Esterle, Ferm, 1994; Domińczak, Okupny, 2010; Borówka $\mathrm{i}$ in., 2015; Rydelek i in., 2015; Ścibior i in., 2015; Kittel i in., 2016; Pawłowski i in., 2016, Zawrzykraj i in., 2017), niż zmienności horyzontalnej (Pawłowski i in., 2014).
Celem pracy była ocena poziomej zmienności podstawowych parametrów fizykochemicznych w strefie przypowierzchniowej niewielkiego torfowiska w dolinie Strugi Wodnej na Wysoczyźnie Lubartowskiej. Analizie poddano: wilgotność, zawartość substancji organicznej, odczyn $(\mathrm{pH})$ oraz pojemność wymiany kationowej (CEC - Cation Exchange Capacity).

\section{LOKALIZACJA \\ I BUDOWA GEOLOGICZNA TORFOWISKA}

Do badań wytypowano torfowisko dolinowe położone w dolinie niewielkiego cieku - Strugi Wodnej, prawostronnego dopływu Kurówki, na Wysoczyźnie Lubartowskiej (ryc. 1).

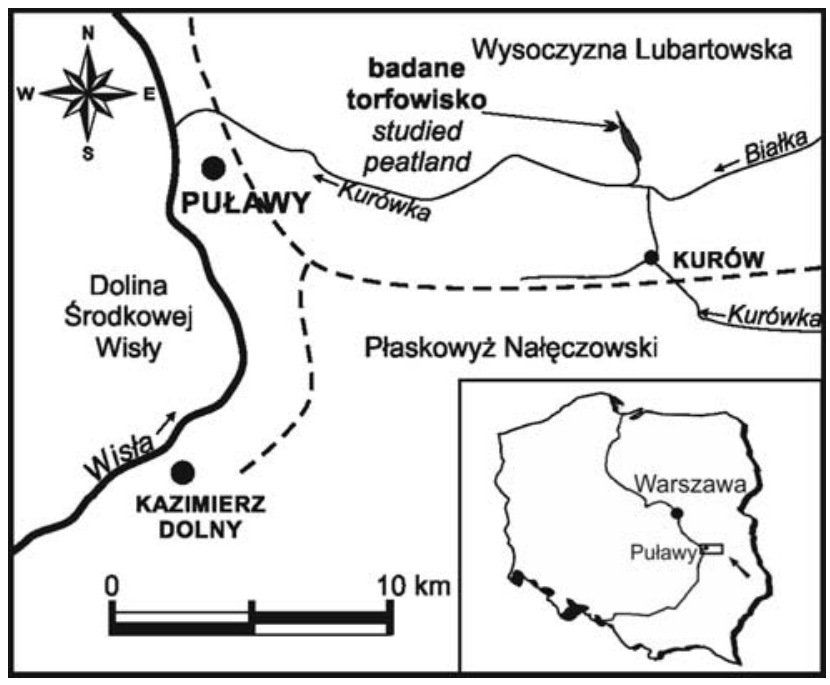

Ryc. 1. Lokalizacja badanego torfowiska (Rydelek, 2011, zmienione)

Fig. 1. Location of the peatland (Rydelek, 2011, modified)

\footnotetext{
${ }^{1}$ Wydział Geologii, Uniwersytet Warszawski, ul. Żwirki i Wigury 93, 02-089 Warszawa; Pawel.Rydelek@uw.edu.pl
} 


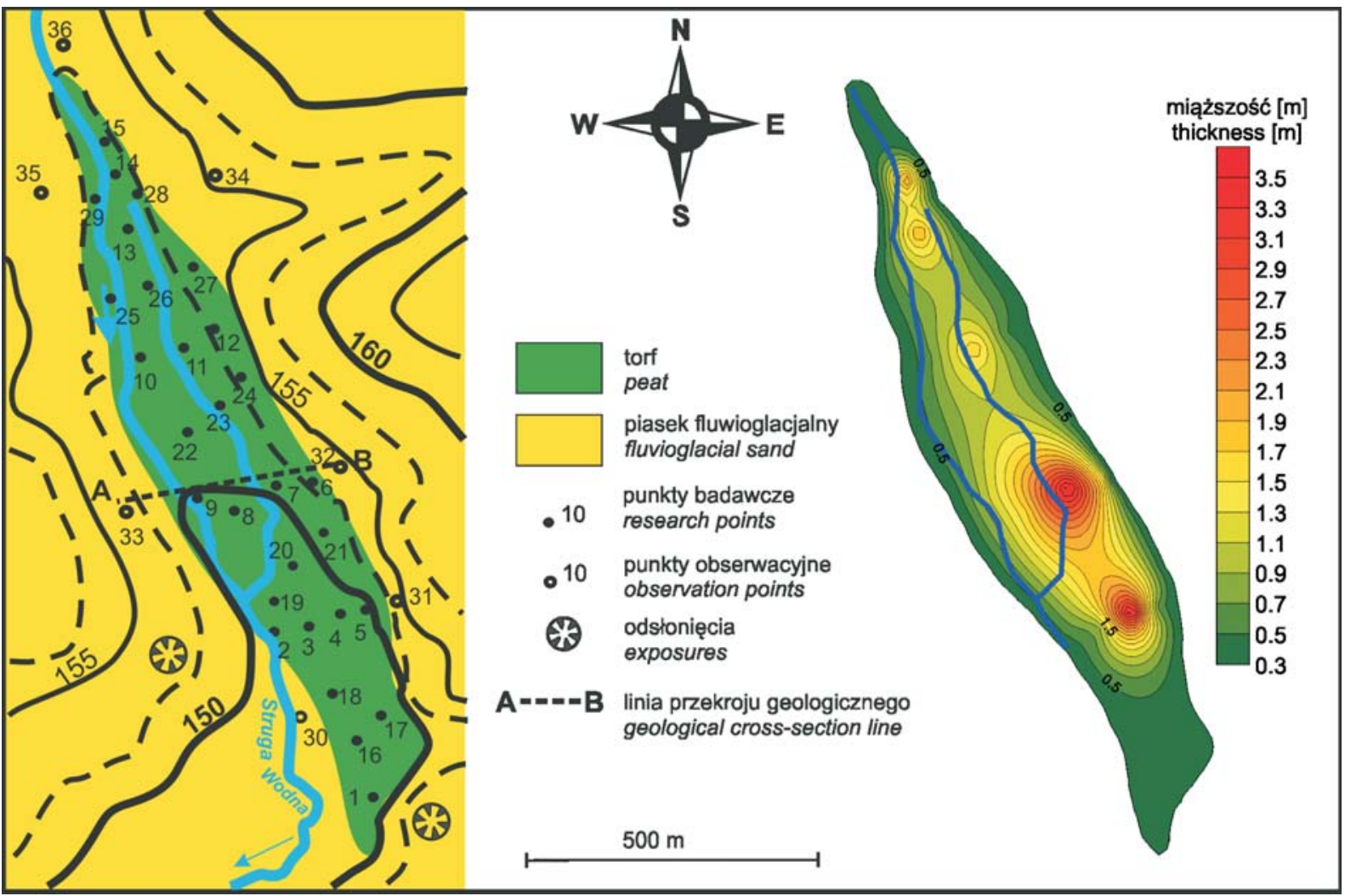

Ryc. 2. Mapa dokumentacyjna i mapa miąższości badanego torfowiska

Fig. 2. Documentation map and thickness map of the peatland

Torfowiska dolinowe zajmują obniżenia w obrębie dolin o różnej genezie, ograniczone przewężeniami, które pełnią rolę progów piętrzących wodę w obrębie doliny. Doliny o podobnym charakterze łączą zazwyczaj obniżenia wytopiskowe lub egzaracyjne (Dembek, 2000). Na omawianym torfowisku Struga Wodna wykształciła dwa wąskie koryta o głębokości ok. 0,5 m. Maksymalna szerokość doliny na badanym odcinku nie przekracza $300 \mathrm{~m}$, a torfowisko zajmuje całą jej szerokość. Powierzchnia torfowiska wynosi ok. 25 ha. Stoki doliny są zbudowane z piasków fluwioglacjalnych tarasów kemowych przylegających do wysoczyzny.

W trakcie badań terenowych w obrębie doliny oraz na jej zboczach wykonano 36 otworów, z czego 29 na torfowisku. Na rycinie 2 przedstawiono mapę dokumentacyjną torfowiska z lokalizacją punktów badawczych i obserwacyjnych oraz mapę miąższości.

W strefie brzeżnej wschodniej i południowej części torfowiska, gdzie miąższość torfów jest najmniejsza, w stropie wystęuje warstwa murszu (punkty: 1, 5, 6, 12, 15, 16, 17, 24, 27), której miąższość osiaga maksymalnie 0,6 m (punkt 6, ryc. 3). Niewielką miąższość murszu stwierdzono również $\mathrm{w}$ centralnej części torfowiska, w sąsiedztwie koryta Strugi Wodnej w punktach: $7(0,4 \mathrm{~m}), 11(0,3 \mathrm{~m})$, $23(0,4 \mathrm{~m})$ i $26(0,3 \mathrm{~m})$.

Torfowisko jest zasilane głównie wodami podziemnymi. Zwierciadło wód podziemnych w obrębie torfowiska występuje na głębokości ok. 0,6 m. Maksymalna miąższość torfów wynosi 3,7 m (punkt 7). Torfowisko jest zbudowane w większości ze słabo rozłożonych torfów szuwarowych, których miąższość osiagga miejscami $2,5 \mathrm{~m}$ (punkt 7). W północnej części torfowiska i w spagowych partiach jego centralnej części występują słabo rozłożone torfy olesowe. Stwierdzona miąższość torfów olesowych w części pół- nocnej osiaga 2,3 m (punkt 14), zaś w części centralnej nie przekracza $1 \mathrm{~m}$. Ponadto w centralnej części torfowiska występują przewarstwienia torfów turzycowiskowych o maksymalnej miąższości 1 m (Rydelek, 2011).

\section{METODY BADAŃ}

Badania wybranych parametrów fizykochemicznych przeprowadzono na 29 próbkach pobranych we wszystkich profilach z przedziału głębokości od 0,3 do $0,5 \mathrm{~m}$. Wilgotność naturalną badanych próbek oznaczono, susząc je w temperaturze $105-110^{\circ} \mathrm{C}$, zaś zawartość substancji organicznej metodą strat prażenia w temperaturze $440^{\circ} \mathrm{C}$ (Myślińska, 2016). Do określenia pojemności wymiany kationowej zastosowano metodę sorpcji miedzi (Sapek, 1986). Metoda zaliczana jest do metod statycznych (batch) i opiera się na pomiarze stężenia jonów miedzi w roztworze przed i po reakcji z gruntem. Odczyn $\mathrm{pH}$ oznaczono metodą elektrometryczną (Myślińska, 2016).

W celu określenia zmienności omawianych parametrów wykorzystano zarówno statystykę opisową, jak i metody geostatystyczne (w tym analizę semiwariogramów), powszechnie wykorzystywane $\mathrm{w}$ różnych dziedzinach nauk o Ziemi (np. Dębowska, Zawadzki, 2005; Słaby i in., 2014; Pawłowski i in., 2014; Janik i in., 2016)

Podstawową funkcją w geostatystyce jest semiwariancja $\gamma(h)$. Opisuje ona zależność między średnim zróżnicowaniem wartości zmiennej $z \mathrm{w}$ danych punktach a odległością h między tymi punktami (Matheron, 1963).

$$
\gamma(h)=\frac{\sum[z(x)-z(x+h)]^{2}}{n} \cdot \frac{1}{2}
$$




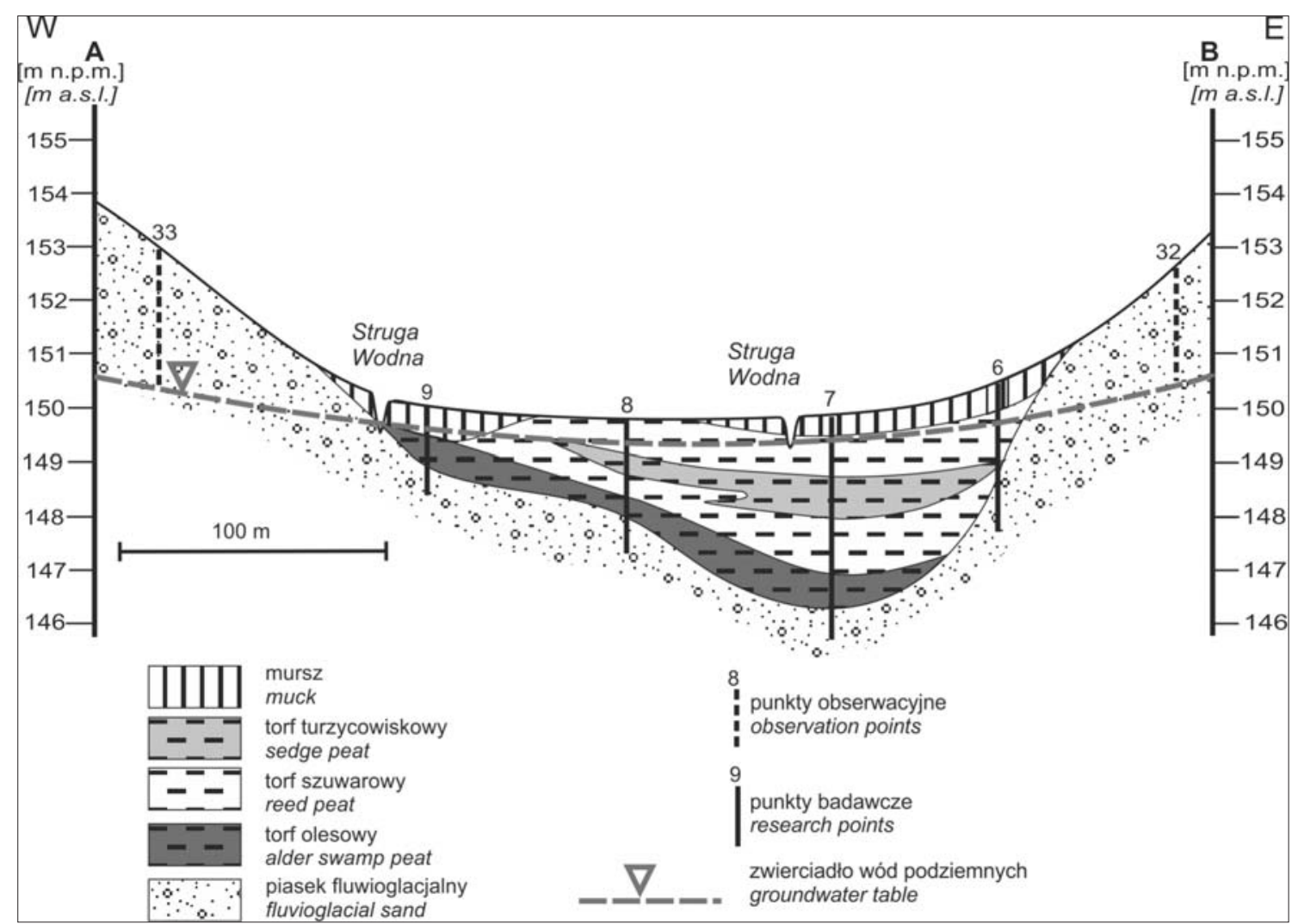

Ryc. 3. Schematyczny przekrój przez badane torfowisko (Rydelek, 2011, zmienione)

Fig. 3. A schematic cross-section of the peatland (Rydelek, 2011, modified)

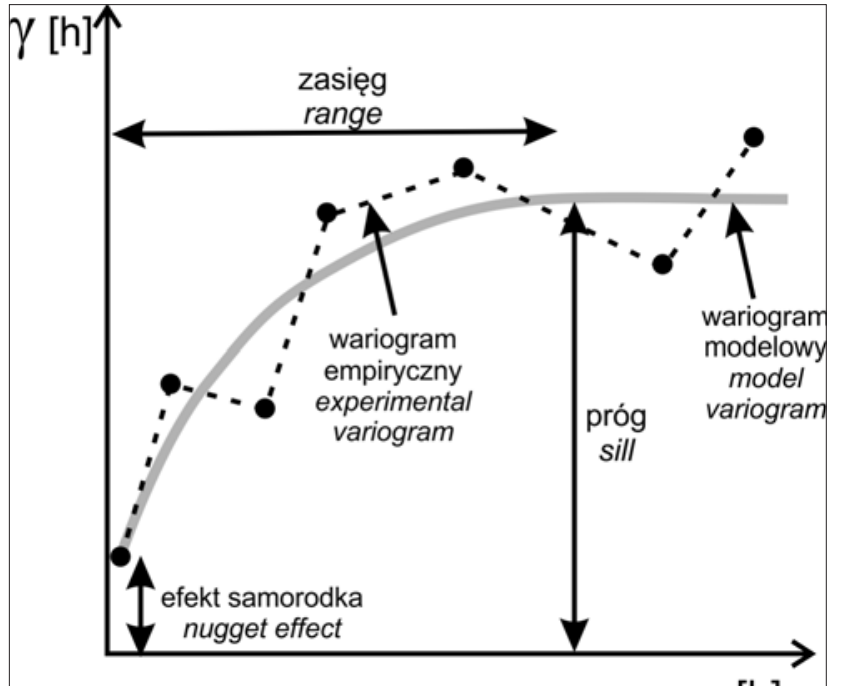

[h]

Ryc. 4. Parametry modelu wariogramu

Fig. 4. Parameters of the variogram model

gdzie:

$\mathrm{z}(\mathrm{x}), \mathrm{z}(\mathrm{x}+\mathrm{h})$ - wartości zmiennej $\mathrm{z} \mathrm{w}$ punktach pomiarowych oddalonych o $\mathrm{h}$

$\mathrm{n}$ - liczba par punktów pomiarowych odległych o h.

Wykres semiwariancji jest zwany semiwariogramem (ryc. 4). Dla semiwariogramu wyróżniane są trzy charakterystyczne parametry: efekt samorodka, próg i zasięg. W przypadku, gdy semiwariogram jest wzrastającą funkcją nie od zera a od pewnej wartości, wartość ta jest nazywana efektem samorodka, który określa zmienność lokalną jaka występuje pomiędzy wartościami w punktach położonych w odległości mniejszej niż krok semiwariogramu (ryc. 4).
Tab. 1. Parametry fizykochemiczne badanych torfów Table 1. Physicochemical parameters of the peats

\begin{tabular}{|l|c|c|c|}
\hline & $\begin{array}{c}\text { Średnia } \\
\text { Min.-max. } \\
\text { Mean } \\
\text { Min.-max. }\end{array}$ & $\begin{array}{c}\text { Odchylenie } \\
\text { standardowe } \\
\text { Standard } \\
\text { deviation }\end{array}$ & $\begin{array}{c}\text { Wspólczynnik } \\
\text { zmienności } \\
\text { Coefficient } \\
\text { of variation }\end{array}$ \\
\hline $\begin{array}{l}\mathrm{OM} \\
{[\%]}\end{array}$ & $\begin{array}{c}60,1 \\
22,0-88,3\end{array}$ & 20,1 & 0,33 \\
\hline $\begin{array}{l}\mathrm{W} \\
{[\%]}\end{array}$ & $\begin{array}{c}335,2 \\
85,0-620,1\end{array}$ & 160,6 & 0,48 \\
\hline $\mathrm{pH}$ & $\begin{array}{c}6,2 \\
5,5-7,1\end{array}$ & 0,5 & 0,07 \\
\hline $\mathrm{CEC}$ & 124,2 & 24,1 & 0,19 \\
{$[\mathrm{cmol} / \mathrm{kg}]$} & $69,3-155,2$ & & \\
\hline
\end{tabular}

OM - zawartość substancji organicznej, w - wilgotność, pH - odczyn, CEC - pojemność wymiany kationowej.

$O M$ - organic matter content, $w$-moisture content, $p H$-acidity, CECcation exchange capacity.

Osiągnięta przez funkcję semiwariogramu wartość, przy której nie obserwuje się dalszego wzrostu funkcji, jest nazywana progiem, natomiast przedział odległości od zera do osiagnięcia przez semiwariogram wartości stałej jest nazywany zasięgiem. Zasięg wyraża największą odległość, przy której badane wartości są ze sobą skorelowane.

\section{WYNIKI}

W tabeli 1 zestawiono wyniki oznaczeń parametrów fizykochemicznych 29 próbek badanych torfów.

Mapy poszczególnych parametrów w strefie przypowierzchniowej torfowiska (ryc. 5) sporządzono na podstawie danych z wszystkich 29 otworów badawczych. Uwzględniono wartości parametrów torfów i murszy 
występujących w strefie przypowierzchniowej w przedziale głębokości $0,3-0,5 \mathrm{~m}$. Do interpolacji wykorzystano metodę krigingu, uwzględniając sferyczny model semiwariogramu. Metodę interpolacji wybrano, wspomagając się procedurą Cross Validation. Polega ona na usuwaniu ze zbioru danych kolejnych punktów i wyznaczaniu w tych punktach wartości zmiennej na podstawie pozostałego zestawu punktów, uzyskując w ten sposób wartość średniego błędu interpolacji. Nieznacznie niższy średni błąd interpolacji wykazała metoda triangulacyjna, jednak do wizualizacji wybrano metodę krigingu, która umożliwia dodatkowo przeprowadzenie analiz przestrzennych.
Mapy wykonano na podstawie skonstruowanych wcześniej semiwariogramów (ryc. 6). Dla poszczególnych parametrów sporządzono semiwariogramy empiryczne, a następnie dopasowano do nich modele teoretyczne (Gumiaux i in., 2003).

\section{DYSKUSJA}

Spośród analizowanych parametrów największą zmienność (wyrażoną za pomocą współczynnika zmienności) wykazała wilgotność torfów (tab. 1). Wilgotność w strefie przypowierzchniowej zawiera się w przedziale od 85 do

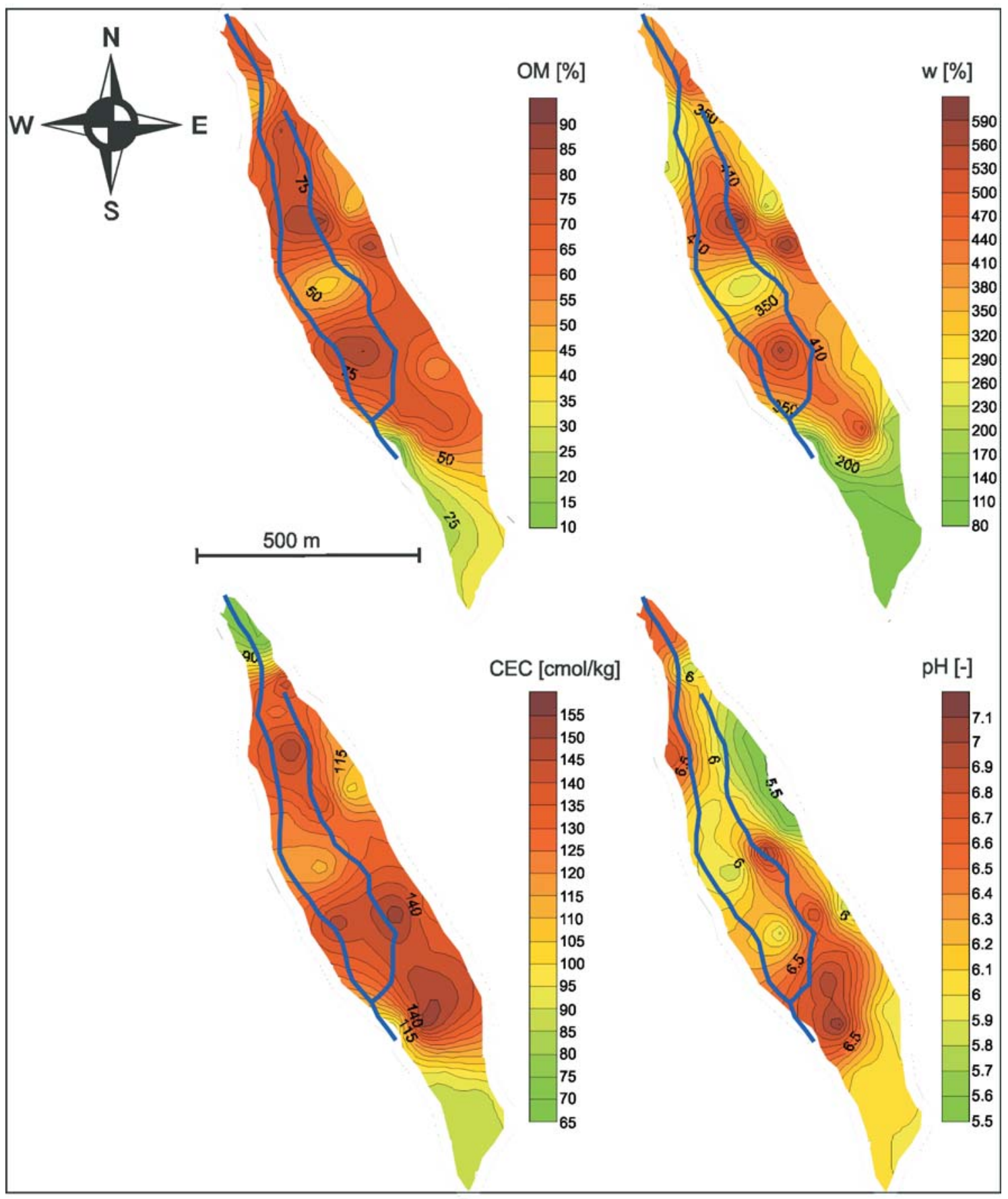

Ryc. 5. Zmienność zawartości substancji organicznej (OM), wilgotności (w), pH i pojemności wymiany kationowej (CEC) w strefie przypowierzchniowej torfowiska

Fig. 5. Variability of organic matter content (OM), moisture content (w), $\mathrm{pH}$ and cation exchange capacity (CEC) in the near-surface zone of the peatland 

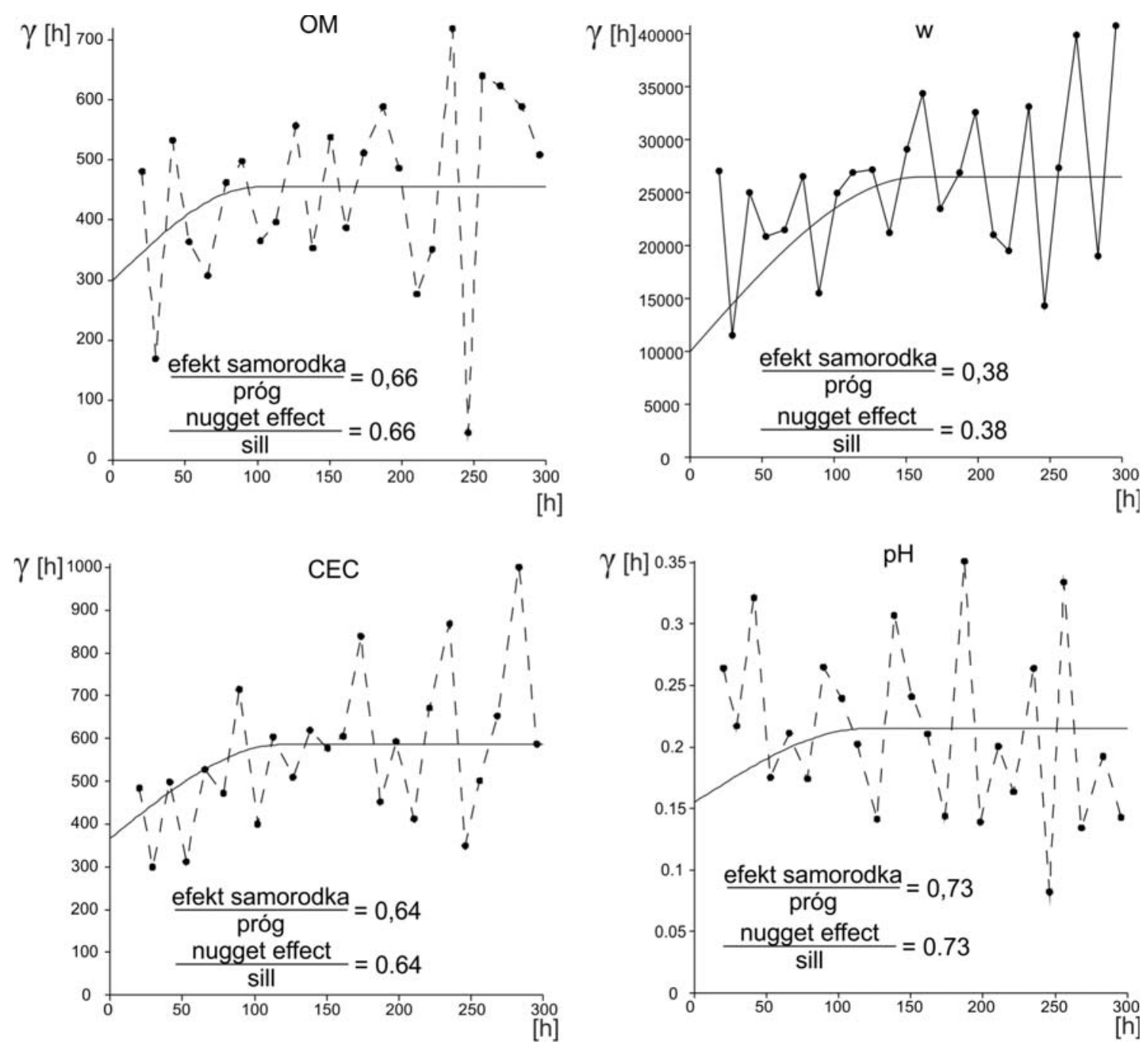

Ryc. 6. Semiwariogramy empiryczne (linia przerywana) i dopasowane modele (linia ciagła) dla parametrów fizykochemicznych badanych torfów. OM - zawartość substancji organicznej, w - wilgotność, pH - odczyn, CEC - pojemność wymiany kationowej

Fig. 6. Experimental semivariograms (the dotted line) and fitted models (solid line) for the physicochemical parameters of the peats. $\mathrm{OM}$ - organic matter content, $\mathrm{w}$ - moisture content, $\mathrm{pH}$ - acidity, $\mathrm{CEC}$ - cation exchange capacity

$620 \%$. Najwyższe wartości wilgotności stwierdzono w obszarach o największej zawartości substancji organicznej. Jest to potwierdzeniem powszechnie opisywanej w literaturze silnej wzajemnej zależności pomiędzy tymi parametrami (np. Hobbs, 1986; Myślińska, 2016; Rydelek i in., 2016). W omawianym przypadku wartość współczynnika korelacji $r$ wynosi 0,87. Zależności pomiędzy wszystkimi parametrami przedstawiono $\mathrm{w}$ tabeli 2 .

Najniższe wartości wilgotności i zawartości substancji organicznej stwierdzono w południowej części torfowiska, gdzie występuje warstwa murszu (punkty 1, 16, 17). Mimo, że mapy rozkładu wilgotności i zawartości substancji organicznej wizualnie wydają się bardzo podobne, analizując poszczególne semiwariogramy zaznaczają się wyraźne różnice. W przypadku wilgotności korelacja przestrzenna zachodzi na dystansie ok. $160 \mathrm{~m}$ (zasięg semiwariogramu $161 \mathrm{~m})$, podczas gdy w przypadku zawartości substancji organicznej zasięg wynosi 102 m. Różnice są widoczne również w przypadku stosunku efektu samorodka do wartości progu. Według Robertsona i in. (1993) wartość ta opisuje niejednorodność przestrzennej autokorelacji - im niższa wartość tego parametru, tym silniejsza przestrzenna autokorelacja korelacja danych. W przypadku wilgotności wartość stosunku wynosi 0,38, co wskazuje na zdecydowanie silniejszą korelację przestrzenną niż w przypadku zawartości substancji organicznej $(0,66)$.

Najniższą wartość współczynnika zmienności spośród omawianych parametrów stwierdzono w przypadku odczynu torfów $(0,07)$. Jednocześnie parametr ten wykazał najwyższą wartość stosunku efektu samorodka do progu $(0,73)$, co wskazuje na niską przestrzenną korelację danych i ich losowy rozkład. Uzyskana wartość jest zbieżna z danymi przedstawionymi przez Pawłowskiego i in. (2014) dla niewielkiego torfowiska w dolinie Grabii. Wartość stosunku efektu samorodka do progu w przypadku odczynu wyniosła dla tego torfowiska 0,84 .

Ponadto wartość współczynnika korelacji dla poszczególnych zależności odczynu z pozostałymi parametrami jest w każdym przypadku niewielka i wynosi od -0,33 do 0,21 (tab. 2).

Ostatnim parametrem, dla którego szacowano zmienność, jest pojemność wymiany kationowej. Otrzymane wartości CEC w badanym torfowisku mieszczą się w zakresie $70-155 \mathrm{cmol} / \mathrm{kg}$ (współczynnik zmienności 0,19 ) i nie odbiegają od uzyskanych przez innych autorów (Kyzioł, 2002; Rippy, Nelson, 2007; Falkowska, 2009). 
Tab. 2.Wartości współczynnika korelacji $r$ dla wszystkich zależności Table 2. Values of the correlation coefficient $r$ for all relationships

\begin{tabular}{|l|c|c|c|c|}
\hline & $\mathbf{p H}$ & $\mathbf{C E C}$ & $\mathbf{w}$ & OM \\
\hline $\mathrm{pH}$ & 1,00 & & & \\
\hline $\mathrm{CEC}$ & 0,21 & 1,00 & & \\
\hline $\mathrm{w}$ & $-0,33$ & 0,56 & 1,00 & \\
\hline $\mathrm{OM}$ & $-0,28$ & 0,66 & 0,87 & 1,00 \\
\hline
\end{tabular}

OM - zawartość substancji organicznej, w - wilgotność, pH - odczyn, CEC - pojemność wymiany kationowej.

$O M$ - organic matter content, $w$-moisture content, $p H$ - acidity, CECcation exchange capacity.

Największe wartości CEC stwierdzono w obszarach znajdujących się w osi doliny, w miejscach, gdzie torfy wykazują wysokie zawartości substancji organicznej. Potwierdza to wartość współczynnika korelacji $(r=0,66)$. Najniższe wartości CEC wykazały mursze położone w strefie brzeżnej na północnym i południowym krańcu torfowiska. Analizując przestrzenną zmienność pojemności wymiany kationowej, obserwowane są podobne zależności jak w przypadku zawartości substancji organicznejzbliżony zasięg (118 m dla CEC i 102 dla OM) oraz podobne wartości stosunku efektu samorodka do progu (odpowiednio 0,64 i 0,66).

\section{PODSUMOWANIE}

Przeprowadzone analizy wybranych parametrów fizykochemicznych torfów występujących w strefie przypowierzchniowej, wskazują na ich duże zróżnicowanie, w tym również przestrzenne. Najniższe wartości wilgotności, zawartości substancji organicznej i pojemności wymiany kationowej, stwierdzono w brzeżnych strefach torfowiska, gdzie miąższość torfu jest najmniejsza, a w strefie przypowierzchniowej występuje warstwa murszu.

Analizując semiwariogramy poszczególnych parametrów, stwierdzono, że w każdym przypadku występuje wysoka lokalna zmienność wyrażona obecnością efektu samorodka. Statystycznie największą zmienność, wyrażoną wartością współczynnika zmienności, wykazała wilgotność torfów, a jednocześnie parametr ten wykazał największą autokorelację przestrzenną. Najniższą autokorelację przestrzenną oraz najniższe wartości współczynnika korelacji $r$, w przypadku zależności z pozostałymi parametrami, wykazał odczyn torfów. Zastosowanie metod geostatystycznych pozwoliło wskazać strefy różniące się właściwościami w obrębie torfowiska oraz określić różnice pomiędzy zmiennością poszczególnych parametrów.

Autor składa podziękowania Panu dr. Zbigniewowi Frankowskiemu oraz anonimowemu Recenzentowi za wnikliwe i cenne uwagi, które przyczyniły się do poprawy pierwotnej wersji artykułu.

\section{LITERATURA}

BORÓWKA R.K., TOMKOWIAK J., OKUPNY D., FORYSIAK J. 2015 - Skład chemiczny osadów bagiennych z doliny Luciąży (torfowisko Beczkowice na Równinie Piotrkowskiej). Folia Quatern., 83 (1): 5-23.

DEMBEK W. 2000 - Wybrane aspekty zróżnicowania torfowisk w młodoi staroglacjalnych krajobrazach Polski wschodniej. Rozprawy habilitacyjne. Wydaw. IMUZ, Falenty.

DĘBOWSKA U., ZAWADZKI J. 2005 - Analiza statystyczna i geostatystyczna zróżnicowania przestrzennego parametrów położenia warstw w NW części Gór Świętokrzyskich. Prz. Geol., 53 (4): 306-310.
DOMIŃCZAK P., OKUPNY D. 2010 - Przestrzenne zróżnicowanie wybranych właściwości fizykochemicznych osadów biogenicznych torfowiska Kopanicha koło Skierniewic. Pr. Geogr., 123: 99-110.

ESTERLE J.S., FERM J.C. 1994 - Spatial variability in modern tropical peat deposits from Sarawak, Malaysia and Sumatra, Indonesia: analogues for coal. Inter. J. Coal Geol., 26 (1-2): 1-41.

FALKOWSKA E. 2009 - Glacial morphogenesis of uplands of the Warta Glaciation in Poland as a control on heavy metal distribution in deposits. Geol. Quart., 53 (3): 293-304.

GUMIAUX C., GAPAIS D., BRUN J.P. 2003 - Geostatistics applied to best-fit interpolation of orientation data. Tectonophysics, 376: 241-259.

HOBBS N.B. 1986 - Mire morphology and the properties and behaviour of some foreign peats. Qarter. J. Eng. Geol., 19: 7-80.

INGRAM H.A.P. 1983 - Hydrology. Ecosystems of the World 4A. [W:] Gore A.J.P. (red.), Mires: swamp, bog, fen and moor. Elsevier, Oxford: 67-158.

JANIK G., BORECKA-STEFANSKA E., DANIEL A., DAWID M., WALCZAK A., JURIK L. 2016 - Estimation of accuracy of surface distribution of volumetric moisture in topsoil layer determined with geostatistical methods. Acta Scient. Polon. Format. Circumiect., 15 (4): $167-179$.

KITTEL P., PŁÓCIENNIK M., BORÓWKA R.K., OKUPNY D., PAWŁOWSKI D., PERON O., STACHOWICZ-RYBKA R., OBREMSKA M., CYWA K. 2016 - Early Holocene hydrology and environments of the Ner River (Poland). Quatern. Res., 85 (2): 187-203.

KYZIOL J. 2002 - Effect of physical properties and cation exchange capacity on sorption of heavy metals onto peats. Pol. J. Environ. Stud., 11 (6): 713-718.

MATHERON G. 1963 - Principles of geostatistics. Econ Geol., 58: 1246-1266

MYŚLIŃSKA E. 2016 - Laboratoryjne badania gruntów i gleb. Wydaw. UW. OKRUSZKO H. 1994 - System of hydrogenic soil classification used in Poland. Bibl. Wiad. Inst. Melioracji i Użytków Zielonych, 84: 5-27.

PAWŁOWSKI D., OKUPNY D., WŁODARSKI W., ZIELIŃSKI T. 2014 - Spatial variability of selected physicochemical parameters within peat deposits in small valley mire: a geostatistical approach. Geologos, 20 (4): 269-288.

PAWŁOWSKI D., BORÓWKA R.K., KOWALEWSKI G.A., LUOTO T.P., MILECKA K., NEVALAINEN L., OKUPNY D., TOMKOWIAK J., ZIELIŃSKI T. 2016 - Late Weichselian and Holocene record of the paleoenvironmental changes in a small river valley in Central Poland. Quater. Sci. Rev., 135: 24-40.

RIPPY J.F., NELSON P.V. 2007 - Cation exchange capacity and base saturation variation among Alberta, Canada, moss peats. Hort Sci., 42 (2): 349-352.

ROBERTSON G.P., CRUM J.R., ELLIS B.G. 1993 - The spatial variability of soil resources following long-term disturbance. Oecologia, 96: 451-456.

RYDELEK P. 2011 - Torfowiska niskie Wysoczyzny Lubartowskiej jako potencjalne naturalne bariery geologiczne. Biul. Państw. Inst. Geol., 446: 407-416.

RYDELEK P. 2013 - Origin and composition of mineral constituents of fen peats from Eastern Poland. J. Plant Nutr., 36 (6): 911-928.

RYDELEK P., BAZKOWSKA A., ZAWRZYKRAJ P. 2015 - Variability of horizontal hydraulic conductivity of fen peats from Eastern Poland in relation to function of peatlands as a natural geological barriers. Geol. Quart., 59: 426-432.

RYDELEK P., BĄKOWSKA A., ZAWRZYKRAJ P. 2016 - Variability of cation-exchange capacity (CEC) of fen peats in vertical profiles from eastern and central poland in relation to function of peat lands as natural geological barriers. Stud. Quatern., 33 (2): 111-116.

SAPEK B. 1986 - Pomiar sorpcji miedzi jako test oceny pojemności sorpcyjnej utworów organicznych. Rocz. Glebozn., 37 (2-3): 343-349.

SŁABY E., DOMONIK A., ŚMIGIELSKI M., MAJZNER K., MOTUZA G., GÖTZE J., SIMON K., MOSZUMAŃSKA I., KRUSZEWSKI Ł., RYDELEK P. 2014 - Protomylonite evolution potentially revealed by the $3 \mathrm{D}$ depiction and fractal analysis of chemical data from a feldspar. Contribut. Mineral. Petrol., 167 (4): 995.

ŚCIBIOR K., RYDELEK P., STĘPIEŃ M. 2015 - Wpływ wybranych torfowisk na kształtowanie składu chemicznego płytkich wód podziemnych Drawieńskiego Parku Narodowego. Prz. Geol., 63 (10/2): 1099-1104.

TOBOLSKI K. 2000 - Przewodnik do oznaczania torfów i osadów jeziornych. Vademecum Geobotanicum. PWN.

ZAWRZYKRAJ P., RYDELEK P., BAKOWSKA A. 2017 - Geo-engineering properties of Eemian peats from Radzymin (central Poland) in the light of static cone penetration and dilatometer tests. Eng. Geol., 226: 290-300.

Praca wpłynęła do redakcji 20.06.2021 r.

Akceptowano do druku 23.07.2021 r. 